\title{
Hydrographic observations from the Weddell Sea during the Norwegian Antarctic Research Expedition 1976/77
}

\author{
ARNE FOLDVIK, TOR GAMMELSRøD AND TOR TØRRESEN
}

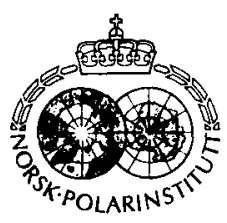

\begin{abstract}
Foldvik, A., Gammelsrød, T. \& Tørresen, T. 1985: Hydrographic observations from the Weddell Sea during the Norwegian Antarctic Research Expedition 1976/77. Polar Research 3 n.s., 177-193.

CTD observations from the southern Weddell Sea in 1977 show that Ice Shelf Water originating under the floating Filchner Ice Shelf overflows at the sill of the Filchner Depression and can be identified on the continental slope at more than $2000 \mathrm{~m}$ depth. Intrusions of Weddell Deep Water upon the shelf are especially noticeable in the region of dense shelf water outflow and are possibly driven by the outflow. Anomalous low core temperature of Weddell Deep Water is probably related to winter convection in the Weddell Polynya. Anomalous CTD stations at the periphery of the 1976 winter polynya region indicate that deep convection phenomena, as reported by Gordon (1978), are perhaps quite common. The observations indicate that double diffusive convection is important for vertical heat transport in the central Weddell Sea.
\end{abstract}

Arne Foldvik, Tor Gammelsrød and Tor Tørresen, University of Bergen, Institute of Geophysics, Department of Oceanography, N-5000 Bergen, Norway; July 1984 (revised July 1985).

The Norwegian Antarctic Research Expedition 1976-77 with the R/V 'Polarsirkel' started from Port Stanley, Falkland Islands, on January 3, 1977 , and ended in Cape Town, South Africa, on March 2, 1977. The multidisciplinary expedition comprised 22 scientists, including a physical oceanography group of three and a crew of 13.

The main effort of the physical oceanography group was concentrated on the continental shelfbreak north of the Filchner Depression and near the Filchner Ice Shelf in connection with studies of bottom water formation. CTD sections were also obtained during the transects from the Falkland Islands to Kapp Norvegia and from Kapp Norvegia to Bouvet Island. The horizontal resolution of these transect sections is relatively coarse due to cruise-time compromises and they do not resolve smail scale features.

For many years it has been known that bottom water is formed at a few locations in polar regions. As early as in 1887 Mohn pointed to a mechanism for bottom water formation in the Greenland Sea; this idea was later explored by Helland-Hansen \& Nansen (1909). The pioneering work of Brennecke (1921), Mosby (1934), and Deacon (1937) showed that the Weddell Sea is another region of special interest for bottom water formation. The bottom water from Antarctica spreads north into the Atlantic, Pacific and Indian Oceans (Deacon 1937; Wust 1938; Reid \& Lynn 1971). Later, several authors have worked with the problem of bottom water formation in the Weddell Sea (Gill 1973; Carmack \& Foster 1975a; Foster \& Carmack 1976a), and it is generally accepted that the Weddell Sea Bottom Water is a mixture involving cold, dense water originating on the continental shelf. The first attempt to directly measure the cold shelf water as it sinks down the continental slope was reported by Foldvik \& Kvinge (1974a), who discussed two current meter records from the shelf break at $40^{\circ} \mathrm{W}$. These records did not reveal any systematic concentrated outflow of dense water from the shelf. It was proposed by Foster \& Carmack (1976a) that the bottom water is produced by shelf edge mixing processes following a rather complicated scheme involving Western Shelf Water, Winter Water and Weddell Deep Water (see definitions below under 'General circulation and water masses').

This was the state of the art in 1977 when our CTD survey on the shelf indicated that potentially supercooled Ice Shelf Water $\left(\theta<-1.9^{\circ} \mathrm{C}\right)$ originating under the Filchner Ice Shelf flowed along the western boundary of the Filchner Depression and over the sill and into the deep ocean. A current meter station was subsequently anchored at the sill to monitor this flow which evidently contributed to the formation of Weddell Sea Bottom Water (see Foldvik et al. 1985). 


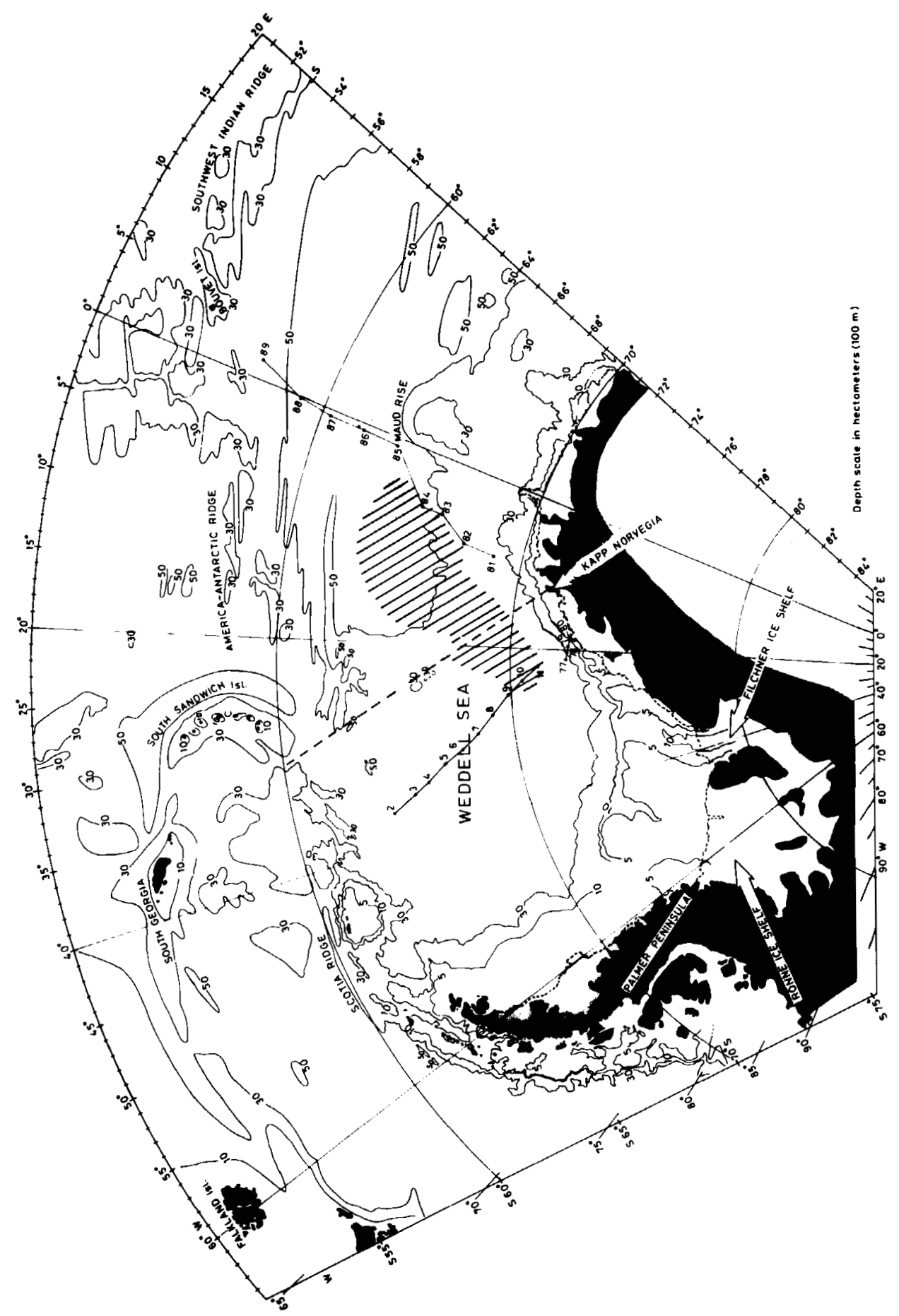

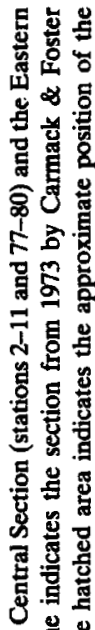

氮品

ठु

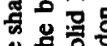

F

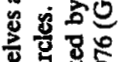

要雪

응 궁

吉兘

亩

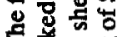

音号䨔

岕的

훙ㅎㅇ

क्ष

辛商管

总象运

동

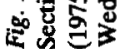




\section{Methods}

Vertical profiles of temperature and conductivity were obtained at 99 stations with a Neil Brown CTD and wire capacity for $3000 \mathrm{~m}$ profiling. The salinities were computed using the formula of Practical Salinity (PSS-78) and standardized against water samples analysed on shore. A r.m.s. error of 0.007 units was obtained.

The CTD data were processed using the programme package by Røyset \& Bjerke (1982). All the plots are based on $2 \mathrm{~m}$ averages of the raw data. The International Equation of State 1980 (EOS-80) was used to calculate the density, and potential temperatures and potential densities are referred to the surface. The section plots are generated using an Akima interpolation routine. The plots are corrected by hand for obvious numerical errors.

One of the main goals on this cruise was to map dense water near the bottom, and the CTD sonde was therefore brought to touch the bottom on most stations in the southern Weddell Sea.

\section{The Weddell Sea. General description}

\section{Bathymetry}

The Weddell Sea area (see Figs. 1 and 2) consists of a $4000-5000 \mathrm{~m}$ deep basin bounded by continental shelves and floating ice shelves to the south-east, south and west, and the Scotia Ridge to the north. The Maud Rise, approximately at the Greenwich meridian, provides a natural eastern boundary. The shelf width varies from less than $100 \mathrm{~km}$ along Queen Maud Land in the south-east to about $500 \mathrm{~km}$ at the Filchner and Ronne Ice Shelves in the south. Underneath these floating ice shelves the continental shelf continues some $600 \mathrm{~km}$ further southward.

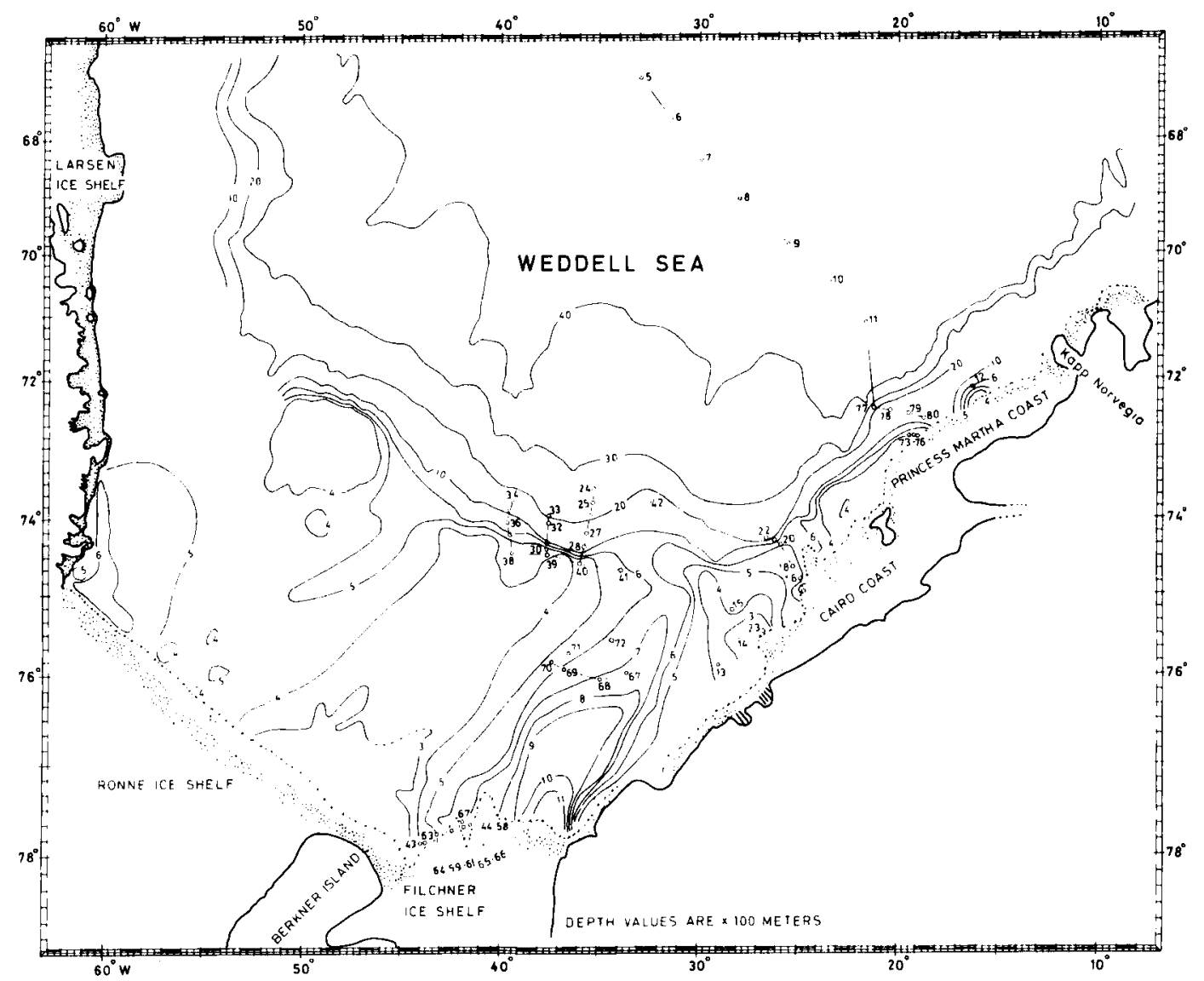

Fig. 2. Map of the southern Weddell Sea. The CTD stations are marked with circles. 
The continental shelves are deep, typically $300-$ $500 \mathrm{~m}$. Near the Filchner Ice Shelf we find the Filchner Depression, which is approximately $1100 \mathrm{~m}$ deep at the ice barrier and has a $600 \mathrm{~m}$ deep sill at the outer edge of the continental shelf. The depression continues underneath the Filchner Ice Shelf where the depth increases (Behrendt 1962). The bathymetry under the ice shelf is poorly known.

The Scotia Ridge forms a boundary against the water masses in the Drake Passage and the Scotia Sea. It has a very irregular shape and a sill depth at about $3000 \mathrm{~m}$ (Carmack \& Foster 1977).

\section{General circulation and water masses}

In the austral winter most of the Weddell Sea is covered with ice, whereas open water is found in the eastern part as far south as the Filchner Ice Shelf during a short period in the summer.
The general large-scale circulation in the Weddell Sea is probably part of an elongated gyre, the Weddell Gyre, between the Palmer Peninsula and 20-30 East (Carmack \& Foster 1975a; Carmack \& Foster 1977; Deacon 1979; Gordon et al. 1981). The circulation is clockwise (cyclonic); it is believed that it extends to the bottom (Carmack \& Foster 1977; Deacon 1979), and that the strongest current speeds are in the western part (Gordon et al. 1981).

In the south-east the cold and relatively fresh Antarctic Coastal Current flows along the continental shelf-break towards the west (Deacon 1937; Gill 1973). At about $27^{\circ} \mathrm{W}$ the current splits up with one branch continuing along the eastern side of the Filchner Depression (Carmack \& Foster 1977). The circulation on the shelf is poorly known.

The dominating water masses in the Weddell Sea are displayed in Fig. 3, which shows a section
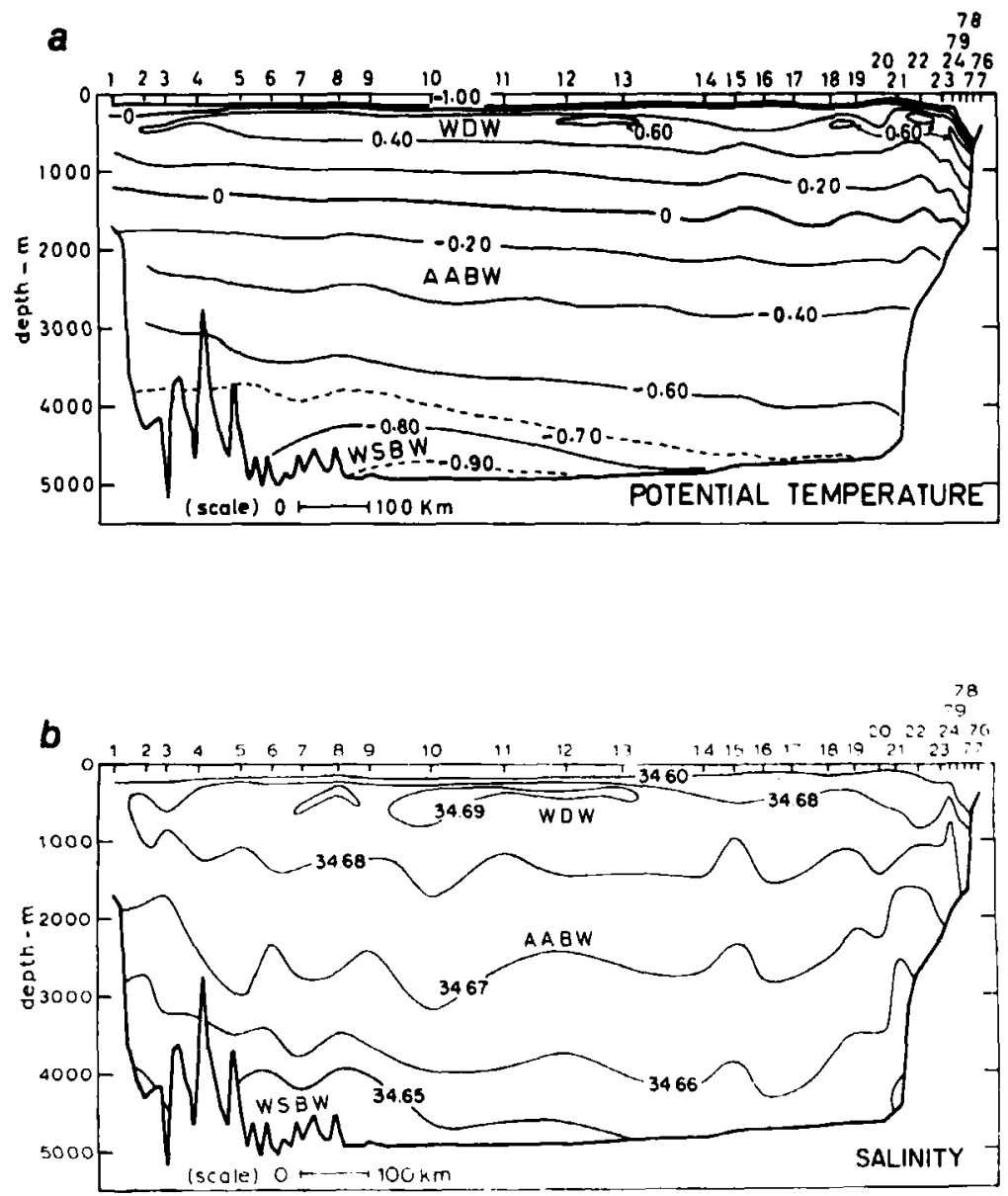

Fig. 3. This section from the Scotia Ridge to Kapp Norvegia shows the distribution of the main Weddell Sea water masses, viz.: Weddell Deep Water (or Warm Deep Water) (WDW), Antarctic Bottom Water (AABW), and Weddell Sea Bottom Water (WSBW). From Carmack \& Foster (1975a). a. Potential temperature; b. Salinity. 


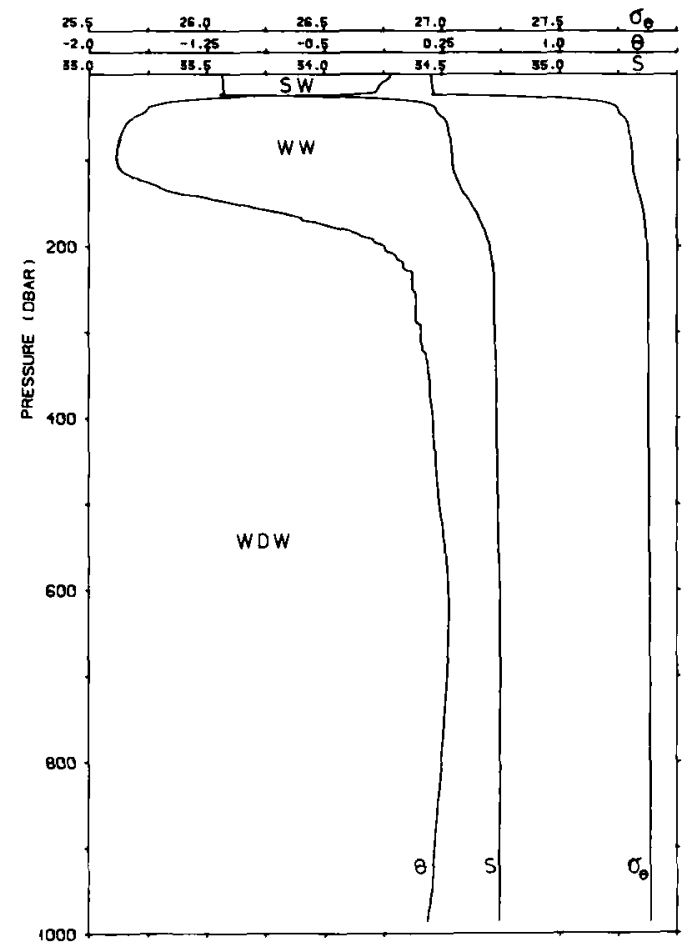

Fig. 4. Typical vertical distribution of potential temperature $(\theta)$, salinity $(S)$, and potential density $\left(\sigma_{\theta}\right)$ in the upper $1000 \mathrm{~m}$ of the central Weddell Sea is shown by CTD station No. 2. The water mass abbreviations are: Surface Water (SW), Winter Water (WW), and Weddell Deep Water (WDW).

from the eastern part of Scotia Ridge to Kapp Norvegia (Carmack \& Foster 1975a). Typical profiles of potential temperature $(\theta)$, salinity (S), and density $\left(\sigma_{\theta}\right)$ from the upper $1000 \mathrm{~m}$ are shown in Fig. 4. The warm, salty layer between $200 \mathrm{~m}$ and $1500 \mathrm{~m}$, with the core usually around $500 \mathrm{~m}$, is the Weddell Deep Water (also called Warm Deep Water) which is characterized by potential temperatures between $0^{\circ} \mathrm{C}$ and $0.8^{\circ} \mathrm{C}$ and salinities between 34.64 and 34.72 (Foster \& Carmack 1976a; Gordon 1982). Above the Weddell Deep Water is Winter Water which maintains its characteristics by haline winter convection due to ice freezing. The Winter Water temperature is near freezing with salinities in the range 34.36 to 34.52 . In summer, ice melting produces a thin, lowsalinity, surface layer of varying temperature (Carmack \& Foster 1975a).

The temperature and salinity decrease gradually below the Weddell Deep Water and from about $1500 \mathrm{~m}$ we find Antarctic Bottom Water with salinities from 34.64 to 34.68 (Foster \& Carmack 1976a). In the south-east this water mass extends all the way to the bottom, but in the south-west, west and north we observe newly formed Weddell Sea Bottom Water at the bottom. It is difficult to distinguish between these two water masses, but Carmack (1973) found that in the transition zone the potential temperature decreases from $-0.6^{\circ} \mathrm{C}$ to $-0.8^{\circ} \mathrm{C}$. Also, Carmack $\&$ Foster (1975a) detected a change in the slope of the potential temperature $v$. salinity curve at $-0.7^{\circ} \mathrm{C}$, and hence they defined Weddell Sea Bottom Water as bottom water with a potential temperature below $-0.7^{\circ} \mathrm{C}$. Consequently, the potential temperature for Antarctic Bottom Water ranges from $-0.7^{\circ} \mathrm{C}$ to $0.0^{\circ} \mathrm{C}$.

The water on the continental shelf east of the Filchner Depression is relatively fresh and the temperature is near freezing point. On the western side of the Filchner Depression the shelf water is also near freezing point, but the salinity is higher due to salt rejection by ice freezing (Mosby 1934; Foster 1972; Gill 1973). Because of this difference the shelf water to the east with salinities between 34.28 and 34.44 is called Eastern Shelf Water, whereas the shelf water to the west with salinities above 34.70 is termed Western Shelf Water (Foster \& Carmack 1976a).

Ice Shelf Water, a water mass with potential temperatures between $-1.9^{\circ} \mathrm{C}$ and $-2.3^{\circ} \mathrm{C}$, is found at depths below 300-400 metres close to the Filchner and Ronne Ice Shelves (Lusquinos 1963; Foldvik \& Kvinge 1974b, 1977; Carmack \& Foster 1975b). Potential temperatures well below the surface freezing point show that this water has acquired its characteristics by cooling at the underside of the floating ice shelves (Sverdrup 1940; Lusquinos 1963). The freezing point of ordinary sea water is lowered by $7.53 \cdot 10^{-4}{ }^{\circ} \mathrm{C} / \mathrm{dbar}$ (Millero 1978), which yields temperatures near the observed ones at the actual depths. Carmack \& Foster (1975b) found that there is a cyclonic circulation in the Filchner Depression. They also found that dense Western Shelf Water with salinity higher than 34.70 sinks down the western slope of the depression and fills up the bottom layers. It is believed that this water is modified under the Filchner Ice Shelf to form the Ice Shelf Water. Ice Shelf Water is less saline than the Western Shelf Water, its salinity ranging from 34.60 to 34.70 . The Western Shelf Water is generally denser than the Ice Shelf Water at all depths (Carmack \& Foster 1975b). The water masses described above are plotted in a potential temperature $v$. salinity diagram in Fig. 5. 


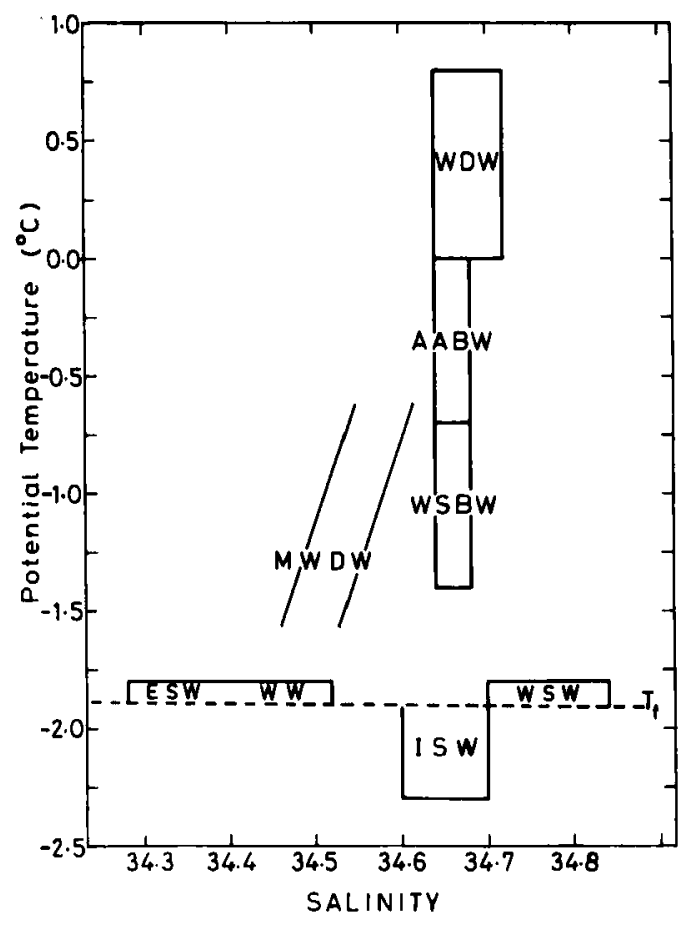

Fig. 5. A schematic representation of the major Weddell Sea water masses is shown in this potential temperature $v$. salinity diagram. $T_{f}$ is the surface freezing point.

\section{Observations}

The Central Section; stations 2-11, 77-80

Possible effects of Weddell Polynya convection. The Central Section consists of stations 2-11 and 77-80 (see map in Fig. 1 and section plots of temperature and salinity in Fig. 6). This section runs parallel to the section obtained in 1973 by Carmack \& Foster (1975a) and discussed in 'General circulation and water masses'. Under a thin $(30 \mathrm{~m})$ fresh and warm summer surface layer we find the Winter Water extending down to $200 \mathrm{~m}$ in the northern part of the section. Below the Winter Water we recognize the Weddell Deep Water with its core at $300-700 \mathrm{~m}$ in the northern part and with core temperatures between $0.2^{\circ} \mathrm{C}$ and $0.3^{\circ} \mathrm{C}$. We further note that the Weddell Deep Water is missing at stations 8-10 while it reappears at station 11 , but here with the core at only $100 \mathrm{~m}$ depth. Closer to the shelf (see stations $77-78$, Fig. 6) the core is found at $200-300 \mathrm{~m}$. At Station 80 , which is near the shelf-break, the core is again down to $700 \mathrm{~m}$ and here the maximum core temperature, $0.6^{\circ} \mathrm{C}$, is reached. The deep core near the shelf is associated with the Antarctic Coastal Current (see Gill 1973). Further south at Section 17-22 (Fig. 7) the core of Weddell Deep Water is located at $900 \mathrm{~m}$ with core temperatures at approximately $0.4^{\circ} \mathrm{C}$. The maximum core temperature in the 1973 section (Fig. 3) was also near the shelf, while it maintained its core temperature of $0.5^{\circ} \mathrm{C}$ at $200-300 \mathrm{~m}$ in the whole section.

A comparison of Figs. 6 and 3 shows that the Weddell Deep Water was $0.2-0.5^{\circ} \mathrm{C}$ colder in 1977 than in 1973. Since the horizontal distance between the Carmack-Foster 1973 section and our Central Section is only about $300 \mathrm{~km}$, we conclude that the Weddell Deep Water was significantly colder in this region in 1977 than in 1973. This conclusion was also reached by Gordon (1982) in his discussion of 'Islas Orcadas' 197678 data.

Gordon (1982) explained this dramatic cooling of the central water mass as a result of the Weddell Polynya described by Martinson et al. (1981). The Weddell Polynya is a large area of open water (over $10^{5} \mathrm{~km}^{2}$ ) which has been observed at preferred localities north of Queen Maud Land during winter in some years (see Fig. 1). Our Central Section and the 'Islas Orcadas' section (Fig. 4 in Gordon 1982) were both obtained in an area where a polynya was observed the preceding winter. In their model for polynya formation and maintenance, Martinson et al. (1981) proposed that if the layer of Winter Water is sufficiently thin, i.e. $150-200 \mathrm{~m}$, then the increase in salinity due to salt rejection during ice formation may produce a surface layer which is denser than the warm Weddell Deep Water underneath. The resultant vertical mixing erodes on the core of Weddell Deep Water and may supply enough heat to melt the sea ice. In turn, the enhanced surface heat transport maintains the convection in the Winter Water and thus sustains the process. We may interpret the missing core of Weddell Deep Water on stations 7-10 and the deep and relatively cold core on stations $2-6$ as different stages of such turbulent erosion. Additional evidence for polynya activity is discussed in 'The Eastern section; stations 81-89'.

Double diffusion. - Individual temperature curves from the Central Section are shown in Fig. 8. Above the core of Weddell Deep Water the general stratification is that of cold, low salinity water overlying warmer and saltier water. This strat- 
a
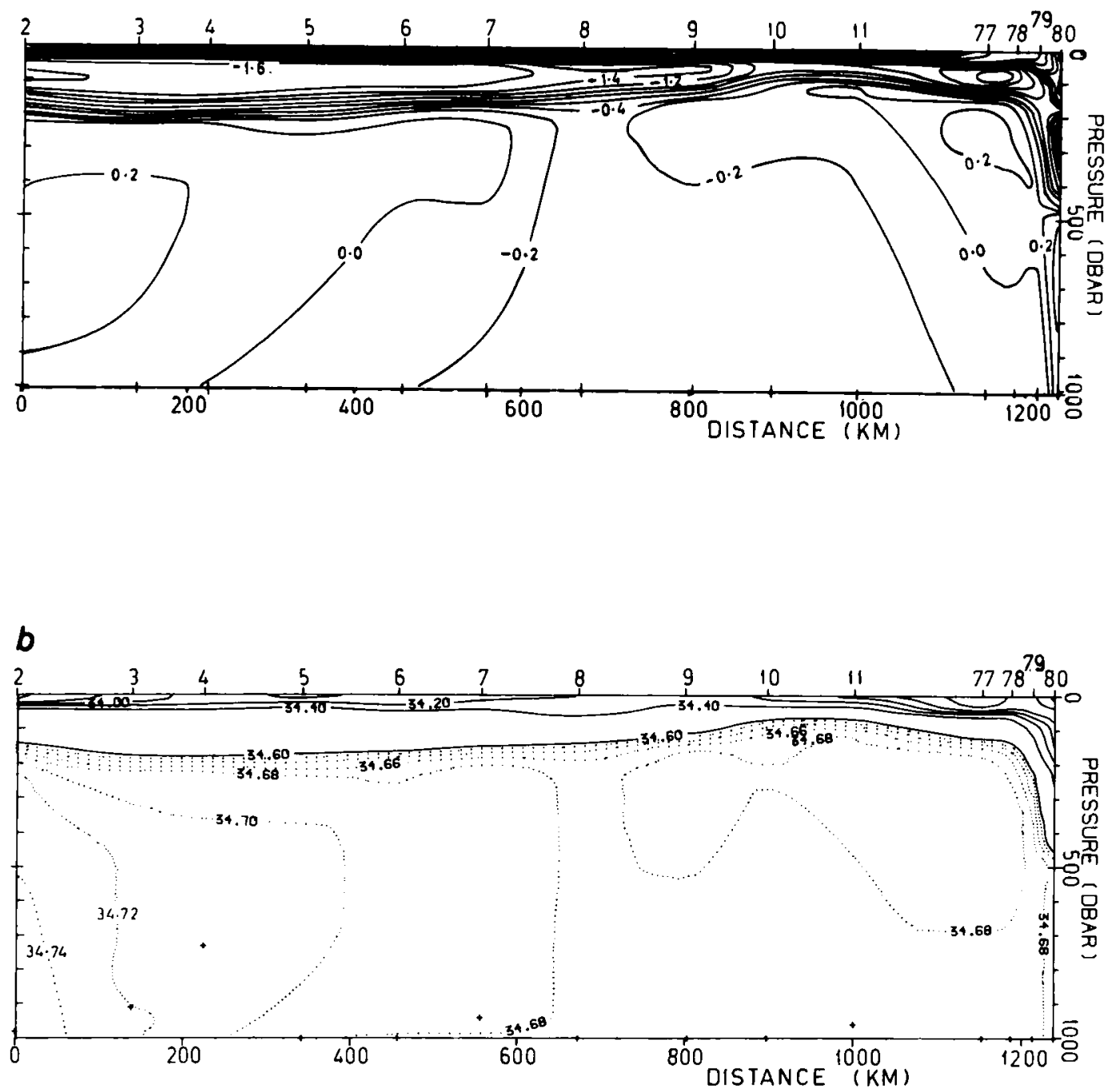

Fig. 6. The Central Section (stations 2-11 and 77-80). For location, see map (Fig. 1). Compare also Fig. 8. Crosses denote maximum depth of individual soundings. a. Potential temperature $\left({ }^{\circ} \mathrm{C}\right) ; \mathrm{b}$. Salinity.

ification favours the formation of convective layers separated by thin interfaces through the process of double diffusion. Observations of extensive double diffusive layers were first obtained from the Arctic Ocean by Neshyba et al. (1971), and later Foster \& Carmack (1976b) and Middleton \& Foster (1980) reported on similar step structures in the centre of the Weddell Sea. From Fig. 8 we note that pronounced step structures exist, being especially well developed over the northern part of the Central Section.
The density ratio $\mathrm{R}_{\rho}=\beta \Delta \mathrm{S} / \alpha \Delta \mathrm{T}$ (where $\beta$ is the coefficient of expansion for salinity changes, $\alpha$ the coefficient of thermal expansion, $\Delta S$ and $\Delta T$ the salinity and temperature differences between two adjacent layers) for the steps in stations 2-7 varies between 1.2 and 1.9 with an average of 1.5. This is higher than reported by Foster \& Carmack (1976b), but in both cases $R_{\rho}$ is less than 2, which indicates unstable double diffusive layers and high vertical transport of heat and salt (Huppert 1971). Presumably, double diffusive processes leading to 

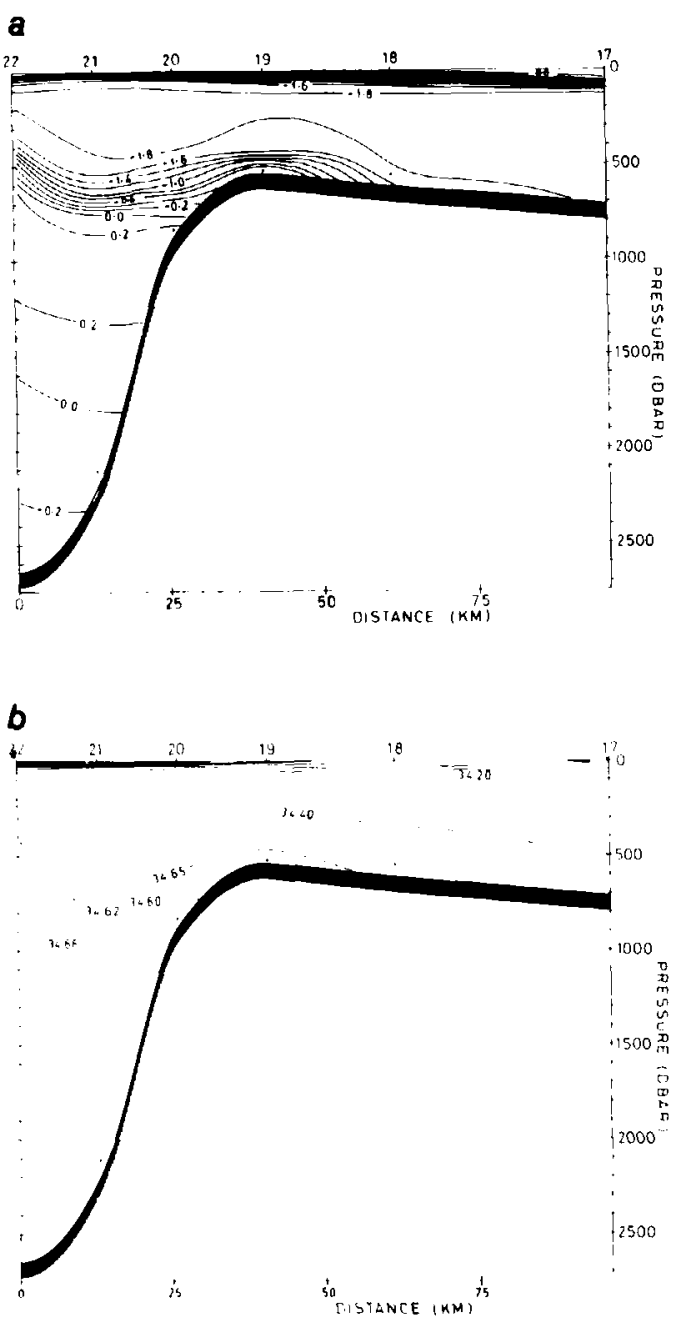

Fig. 7. Section 17-22. For location, see map (Fig. 2). Crosses denote maximum depth of individual soundings. a. Potential temperature $\left({ }^{\circ} \mathrm{C}\right)$; b. Salinity.

enhanced vertical transport of heat and salt are also important during the active polynya convection. Due to the extreme surface heat loss such double diffusive processes will presumably act less stabilizing on polynya convection.

\section{The Eastern Section; stations 81-89}

The other long section consists of stations 81-89 (Fig. 9) and crosses the Weddell Gyre from northeast of Kapp Norvegia $\left(68^{\circ} 32^{\prime} \mathrm{S}, 8^{\circ} 37^{\prime} \mathrm{W}\right)$ towards Bouvetöya $\left(57^{\circ} 07^{\prime} \mathrm{S}, 1^{\circ} 22^{\prime} \mathrm{E}\right)$. At this longitude the westward flowing Weddell Deep Water is 'normally' warmer than the eastward flowing
Weddell Deep Water further north (Deacon 1979). The transition zone between the eastward and westward flowing Weddell Deep Water in the gyre is located around 63-64'S (Deacon 1979), which means somewhere between stations 84 and 86. Accordingly, the warmest Weddell Deep Water ( $\mathrm{T}=0.6^{\circ} \mathrm{C}$ at stations 83 and 84 ) is situated to the south of the transition zone and flows westward. This warm Weddell Deep Waier enters the area of the Weddell Polynya and its heat content has not yet been sensibly reduced by polynya convection (compare previous section).

The border between the eastward flowing Weddell Deep Water and the Circumpolar Deep Water is approximately at the southern edge of the America-Antarctic Ridge and the Southwest Indian Ridge (Deacon 1979) (see Fig. 1). The deepening of the isotherms and isohalines at the northern end of the Eastern Section probably indicates the southern part of this border.

Cold-core eddies in the Polynya region. - An anomalous thermohaline stratification is found at station 82 (Fig. 9). The Winter Water is warmer than normal and the Weddell Deep Water is replaced by a colder and less saline water mass. Two weeks earlier Gordon (1978) observed an eddy only $50 \mathrm{~km}$ north-east of station 82 . This was a cold-core eddy with low salinity, high oxygen and cyclonic flow which extended to at least $4000 \mathrm{~m}$ depth. Gordon (1978) suggests there are several eddies in the area. Station 82 might thus represent a similar eddy or the same eddy as the one observed by Gordon. In the latter case the eddy has moved with an average speed of $8 \mathrm{~cm} / \mathrm{s}$. Note that the scale of the eddy observed by Gordon is only about $30 \mathrm{~km}$. This scale is not resolved in our Eastern Section (Fig. 9), which has too large station spacing $(100-200 \mathrm{~km})$. A similar anomalous structure is seen in the Central Section (Fig. 6), where station 8 is homogeneous below $200 \mathrm{~m}$ depth and where the WDW is absent at stations 8-10. The Winter Water is, however, colder here than at station 82 (Fig. 9). The area occupied by the Weddell Polynya during the preceding winter season is sketched in Fig. 1, and it is seen that both the anomalous stratifications observed in Figs. 6 and 9 are situated at the periphery of the polynya. The small horizontal scale of the eddy observed by Gordon (1978) is admittedly not resolved by our station net. However, the fact that anomalous stratifications are observed which resemble the vertical structure 


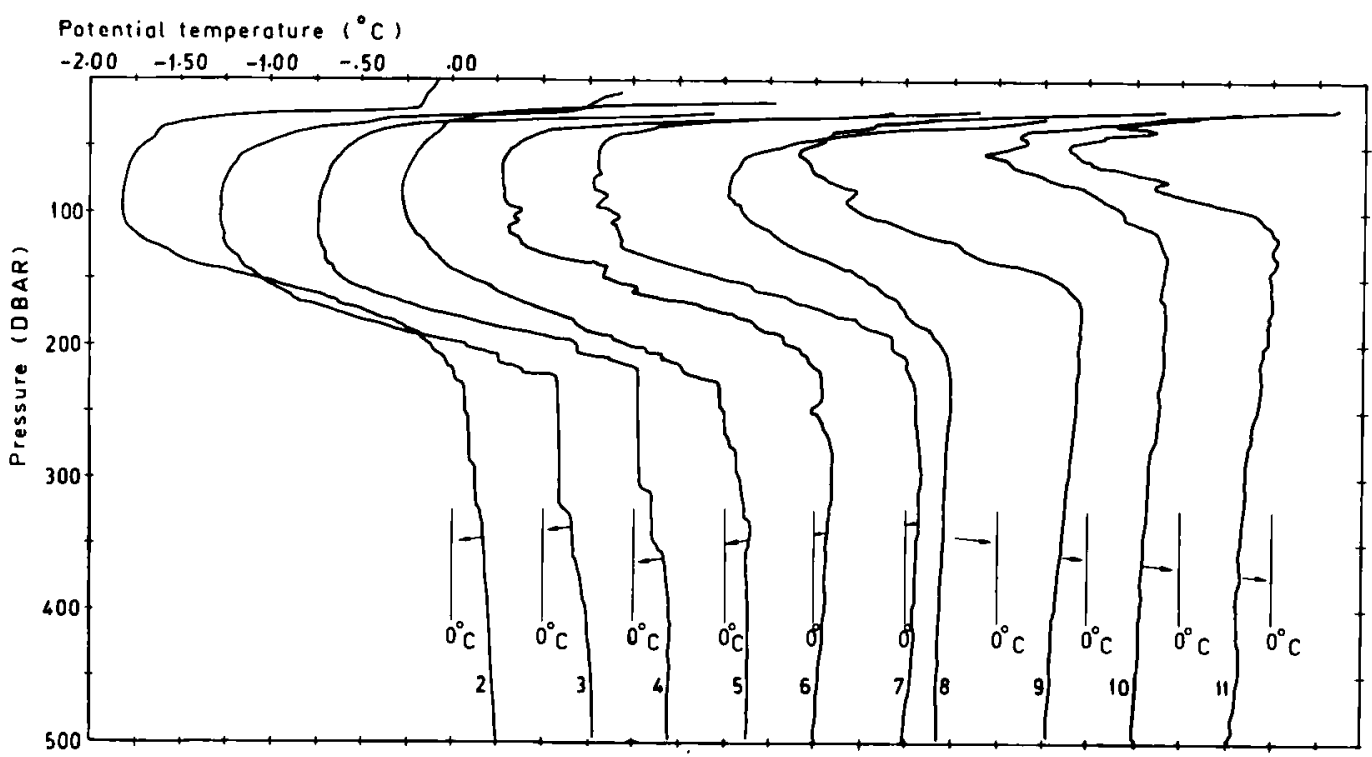

Fig. 8. Temperature profiles for stations 2-11. For location, see map (Fig. 1). The temperature scale for station No. 2 is shown in the upper left corner. Consecutive profiles are displaced $0.5^{\circ} \mathrm{C}$ to the right of the previous station profile.

in the observed eddy indicates to us that such deep convection phenomena are perhaps quite common during intense polynya years.

\section{The Antarctic Coastal Current}

The Antarctic Coastal Current mentioned previously is recognized in the Central Section as a wedge of cold, fresh surface water against the coast (station 80). Further south, at Section 1722 (Fig. 7), this current is not so clearly identified. According to the observations of Foster \& Carmack (1976a) (see 'General circulation and water masses'), the current splits up at this location with one branch following the eastern side of the Filchner Depression.

In the Slope Sections (Figs. 15, 17 and 18), Weddell Deep Water and fresher mixtures of Weddell Deep Water and Winter Water show a tendency to intrude upon the shelf. These intrusions are relatively permanent features at the shelf-break, but presumably considerable variations in time and space occur (compare Foster \& Carmack 1976a). This area west of the Filchner Depression is the site for heavy, cold water leaving the shelf (see below). In the process it mixes with and removes overlying warmer water. The observed intrusion of Weddell Deep Water may thus be looked upon as a compensating flow. In support of this interpretation we note that Slope Section East at $36^{\circ} \mathrm{W}$ (Fig. 15), which shows the most pronounced intrusion, is located at a site of considerable dense water outflow.

\section{The Ice Shelf Water}

How the floating ice shelf modifies the surrounding water masses is demonstrated in Fig. 10, where $T, S$, and sigma-t profiles of station 60 near the Filchner Ice Shelf are presented. In the upper $200 \mathrm{~m}$ the temperature is slightly above the freezing point at atmospheric pressure. At $200 \mathrm{~m}$ there is a sudden temperature decrease of about $0.2^{\circ} \mathrm{C}$ down to $-2.07^{\circ} \mathrm{C}$, which is near the in situ freezing point. There is no corresponding jump in the salinity. From 200 to $400 \mathrm{~m}$ the temperature remains close to $-2.07^{\circ} \mathrm{C}$ while the salinity increases slowly. This is probably Eastern Shelf Water which has been cooled by the ice shelf. At $400 \mathrm{~m}$ there is another jump in temperature, but here it is associated with an increase in salinity. The temperature decreases to $-2.27^{\circ} \mathrm{C}$, which is slightly below the in situ freezing point, and the salinity increases to above 34.6. This water mass below $400 \mathrm{~m}$ is recognized as Ice Shelf Water (Fig. 5). As mentioned above, the saline Western Shelf Water fills up the deep parts of the Filchner Depression. This depression continues several 

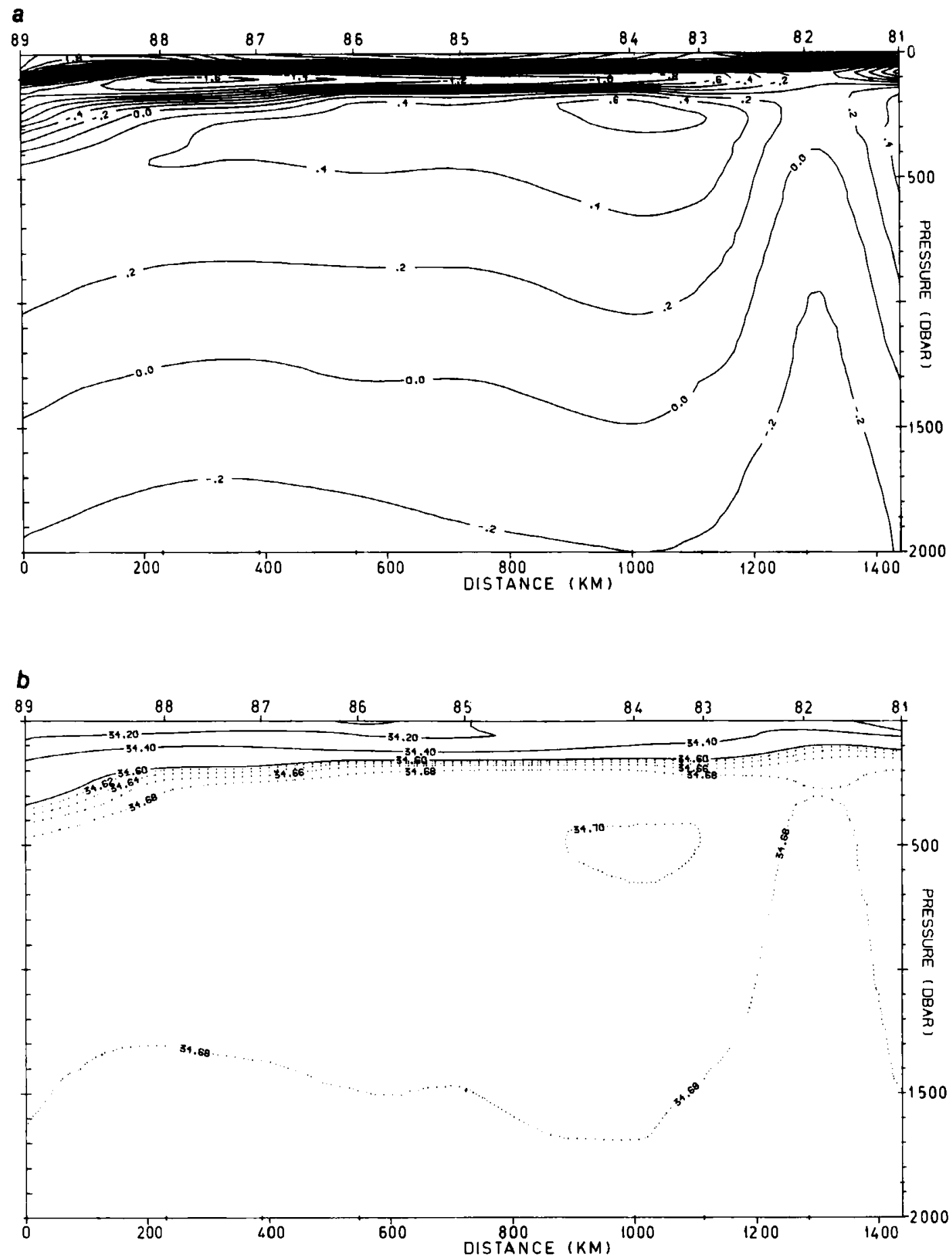

Fig. 9. The Eastern Section (stations 81-89). For location, see map (Fig. 1). Crosses denote maximum depth of individual soundings. a. Potential temperature $\left({ }^{\circ} \mathrm{C}\right)$; b. Salinity. 


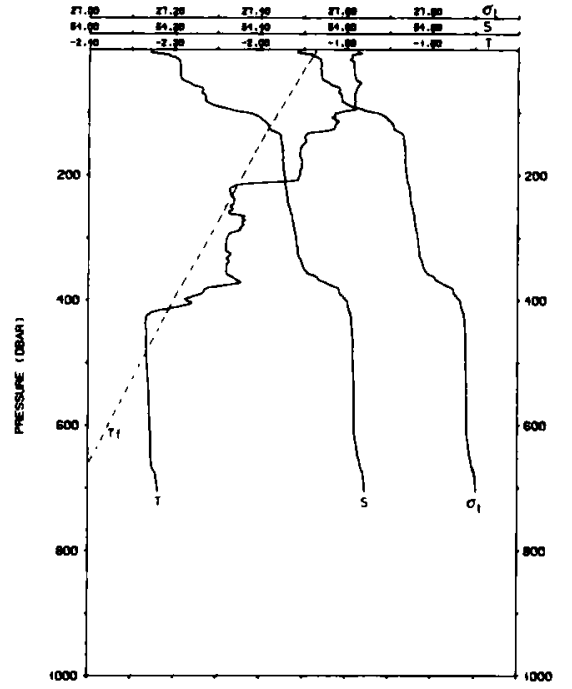

Fig. 10. Vertical profiles of temperature, salinity and density at station 60. The in situ freezing point curve (Millero 1978) is marked $T_{f}$.

hundred kilometres underneath the ice shelf, and here the Western Shelf Water is cooled and diluted by meltwater to form the Ice Shelf Water.

We have calculated the in situ freezing point using the formula by Millero (1978) and the observed salinity. This curve is indicated in Fig. 10 as a dotted line and intersects the temperature curve at $200 \mathrm{~m}$ and $400 \mathrm{~m}$ where the water is in situ supercooled. Foldvik \& Kvinge (1977) also observed in situ supercooled Ice Shelf Water in the area and explained it as a result of upward displacement of water at its in situ freezing point. At station 60 the supercooling at $400 \mathrm{~m}$ is about $0.04^{\circ} \mathrm{C}$, which could be produced by an upward displacement of $55 \mathrm{~m}$.

On a location near station 60 twelve CTD stations were obtained during a 30 -hour period (see Fig. 11). These stations are very similar to station 60 with Ice Shelf Water below $400 \mathrm{~m}$. However, the cold Eastern Shelf Water at $200 \mathrm{~m}$ is not so distinct. Also the in situ supercooling at $400 \mathrm{~m}$ is smaller and intermittent due to alternating currents.

Stations $67-70$ define a section at the western slope of the Filchner Depression (see Fig. 12). Our interpretation of this section is that saline Western Shelf Water $(S>34.7)$ drains into the Filchner Depression below the Ice Shelf Water, which is seen as a core of minimum temperature at about $500 \mathrm{~m}$. See also Fig. 13 for the plot of station 68 and Carmack \& Foster (1975b).

Further north at the Outer Shelf Section, stations 38-41 (Fig. 14), the Ice Shelf Water appears near the bottom at station 41 . Here it leaves the shelf-break, flowing towards the north-west across the isobaths under the influence of coriolis, gravitational, and frictional forces. We recognize the Ice Shelf Water at $1500-2000 \mathrm{~m}$ depth near $36^{\circ} \mathrm{W}$ in the Slope Section East, stations $24-28$ and 40 (Fig. 15), as a thin $(\sim 100 \mathrm{~m})$ cold layer near the bottom. This is demonstrated in Fig. 16, which shows the temperature profiles from the

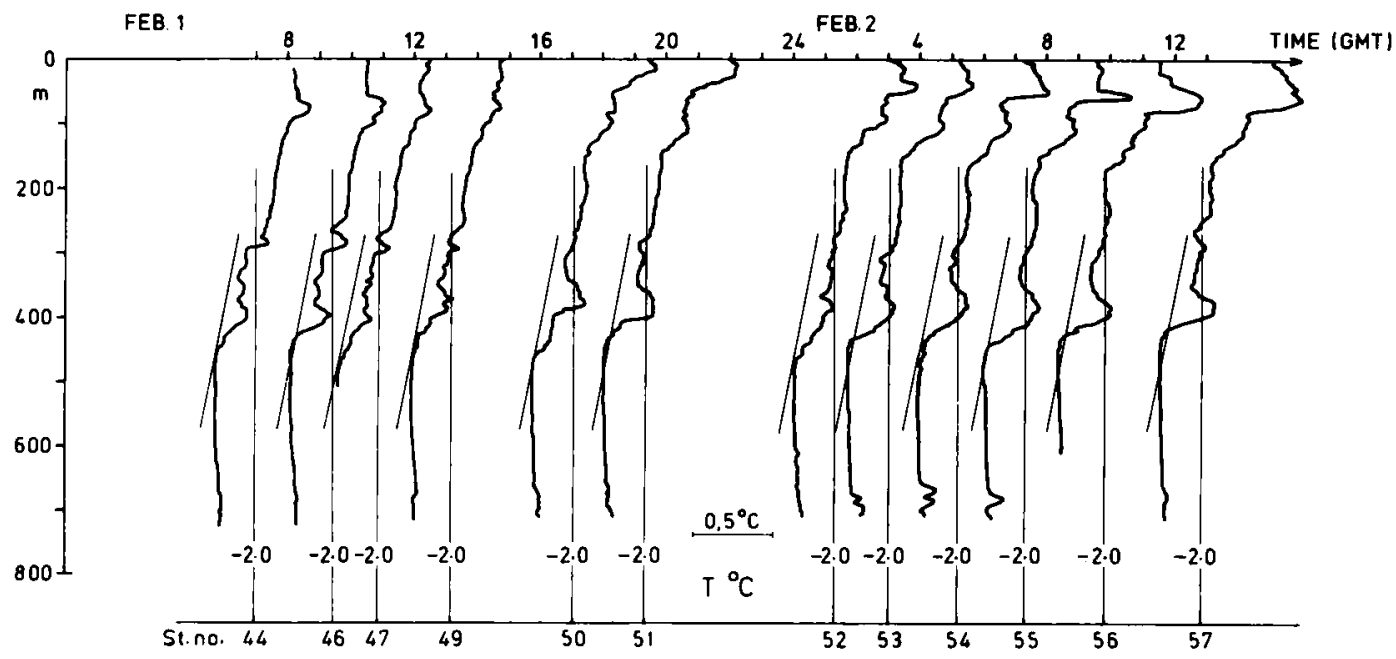

Fig. 11. Temperature profiles at the Filchner Ice Shelf (stations 44-57). For each station the $-2^{\circ} \mathrm{C}$ isotherm is referred to the time of observation. The thin slanting lines show the in situ freezing point $\left(T_{f}\right)$. 

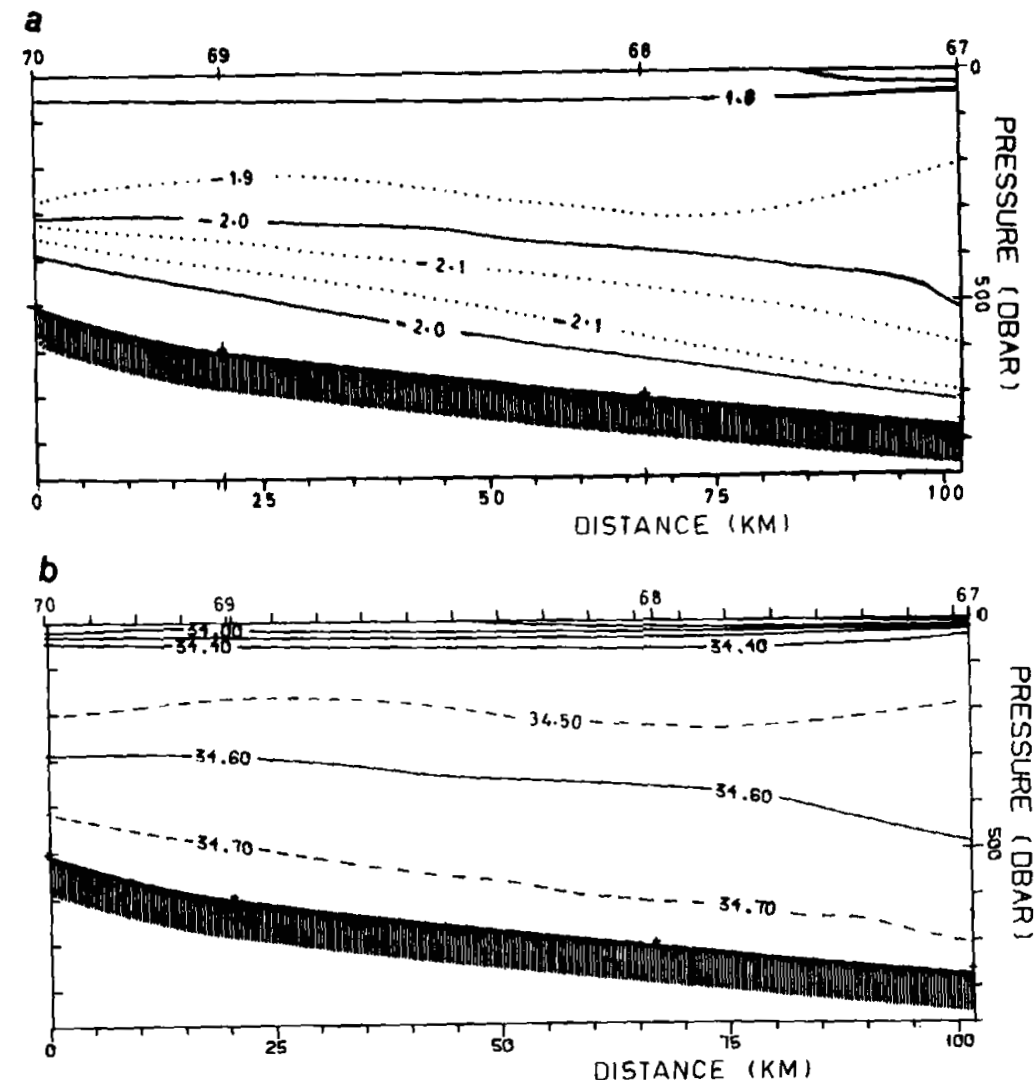

Fig. 12. Filchner Depression Section (stations 67-70). For location, see map (Fig. 2). Crosses denote maximum depth of individual soundings. a. Potential temperature $\left({ }^{\circ} \mathrm{C}\right)$; b. Salinity.

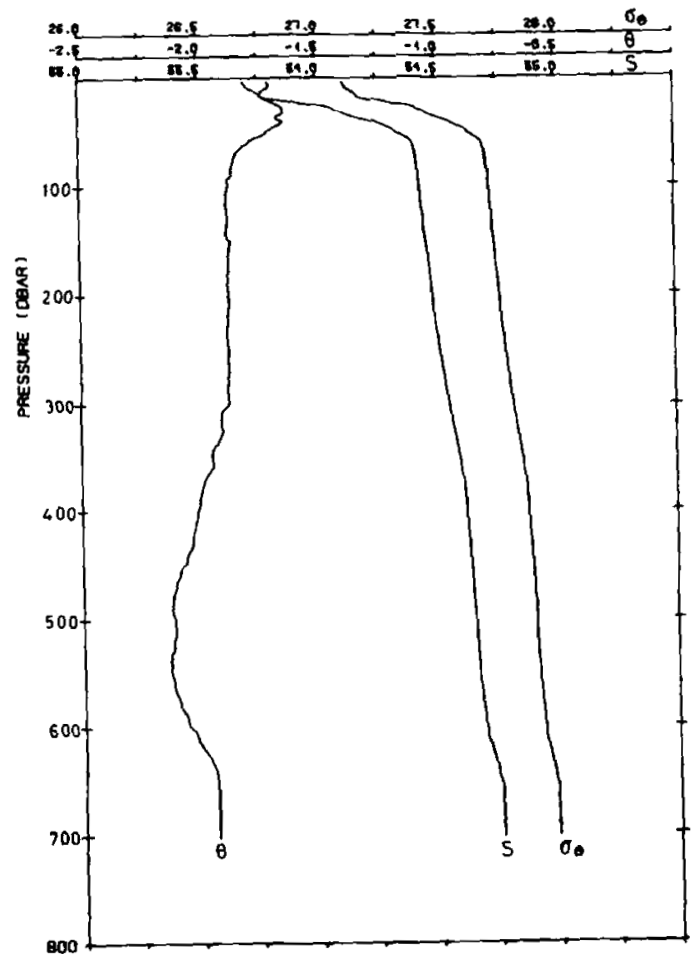

Fig. 13. Vertical profiles of potential temperature, salinity and potential density at station 68 . 
Fig. 14. Outer Shelf Section (stations 38-41). For location, see map Fig. 2. Crosses denote maximum depth of individual soundings. a. Potential tem. perature $\left({ }^{\circ} \mathrm{C}\right)$; b. Salinity.
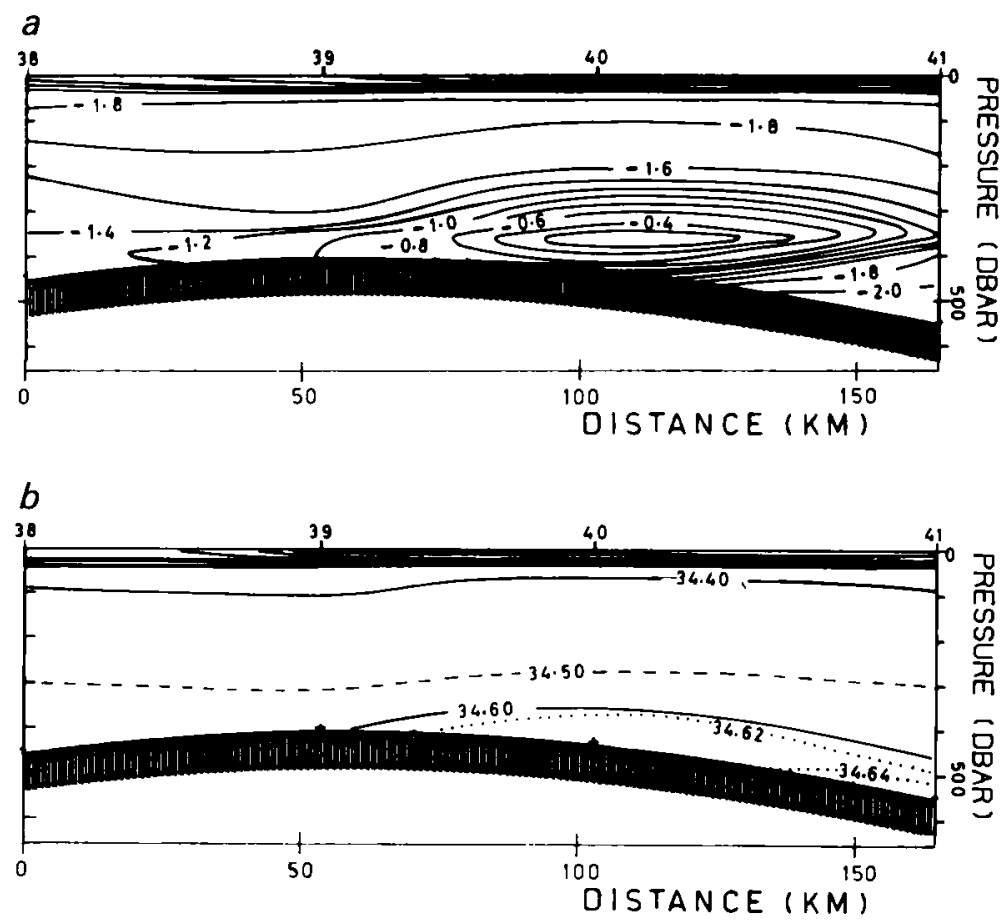

stations in the Slope Sections East. At station 28 there is a nearly homogeneous $120 \mathrm{~m}$ thick layer of Ice Shelf Water at the bottom. The amount of Ice Shelf Water decreases both upwards and downwards on the continental slope. Following the path from the Outer Shelf Section to the Slope Section East, the Ice Shelf Water seems to descend roughly 1 metre per 100 metres. In the Slope Section Centre (Fig. 17) further west it is therefore expected to have reached a depth of more than $2000 \mathrm{~m}$, which is probably the reason why we do not observe it at either the Slope Section Centre or at the Slope Section West (Fig. 18).

\section{Summary}

This paper presents results of CTD measurements obtained during the Norwegian Antarctic Research Expedition 1976-77 to the southern Weddell Sea. In particular we note the following points:

I. The considerable year-to-year change $\left(\sim 0.5^{\circ} \mathrm{C}\right)$ in core temperature of Weddell Deep Water is probably related to anomalous winter convection during polynya years.
II. In the central Weddell Sea we observe a step structure above the Weddell Deep Water core due to double diffusive processes. Double diffusive convection is probably important for the vertical heat transport in the region.

III. An anomalous CTD station off Kapp Norvegia is believed to indicate a cold-core eddy similar to the one (possibly the same) reported by Gordon (1978). Other anomalous CTD stations on the south-western periphery of the 1976 winter polynya region indicate that such deep convection phenomena are perhaps quite common.

IV. We observe intrusions of warm Weddell Deep Water upon the shelf at $36-40^{\circ} \mathrm{W}$ (see also Foster \& Carmack 1976a). Such intrusions are possibly driven by the outflow of dense shelf water.

V. Our observations confirm the picture of the circulation in the Filchner Depression as described by Carmack \& Foster (1975b), viz.: Extremely dense Western Shelf Water drains into the Depression where it takes part in and maintains a clockwise circulation. 

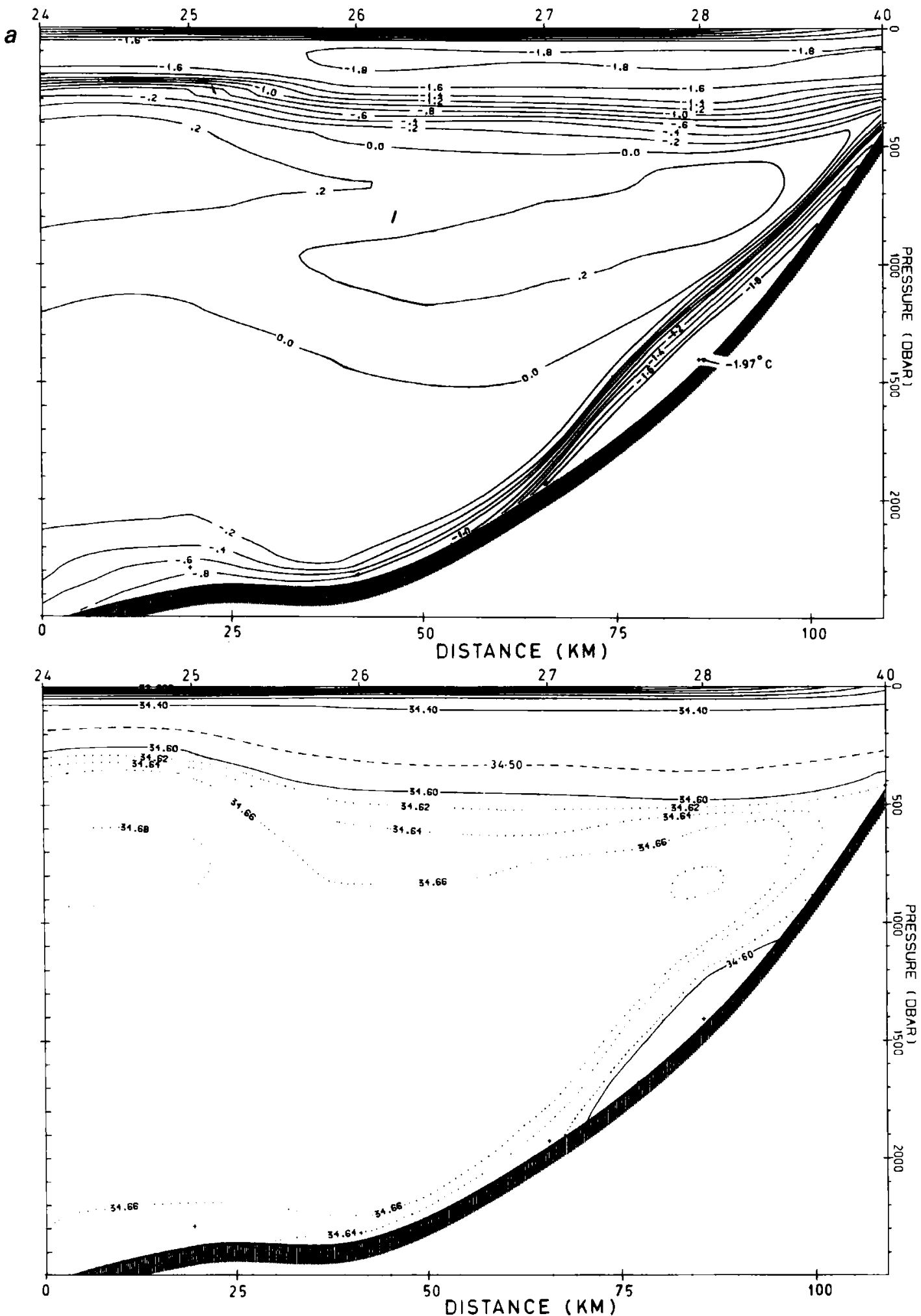

Fig. 15. Slope Section East (stations 24-28 and 40). For location, see map (Fig. 2). Crosses denote maximum depth of individual soundings. a. Potential temperature $\left({ }^{\circ} \mathrm{C}\right) ;$ b. Salinity. 
Fig. 16. Vertical temperature profiles for stations $24-28$ and 40.

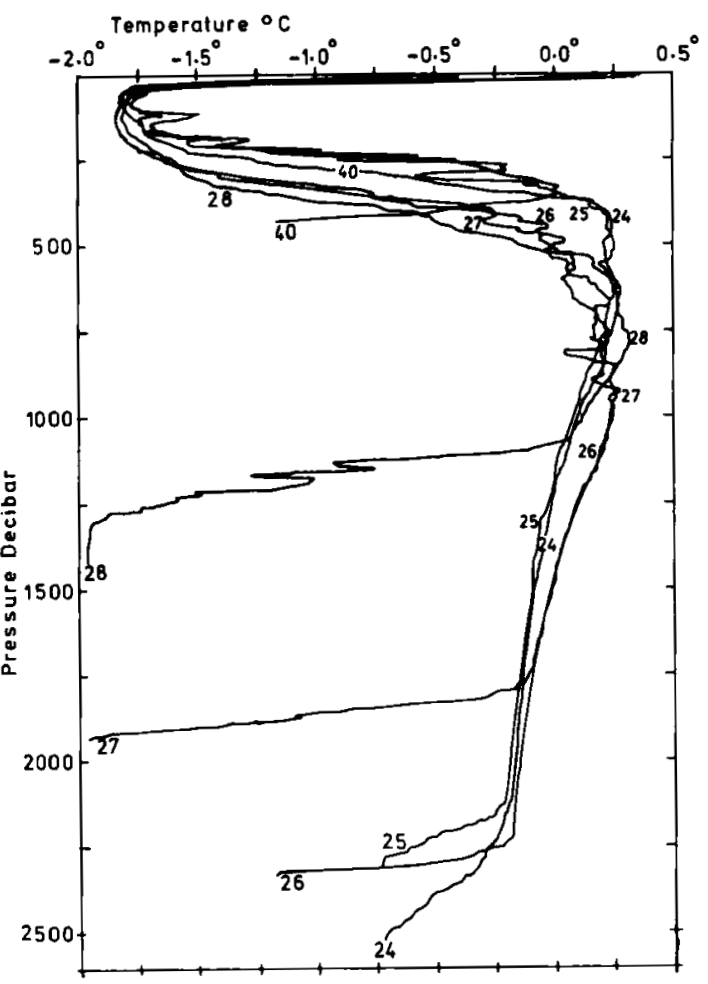
Compare also section Fig. 15a.

a

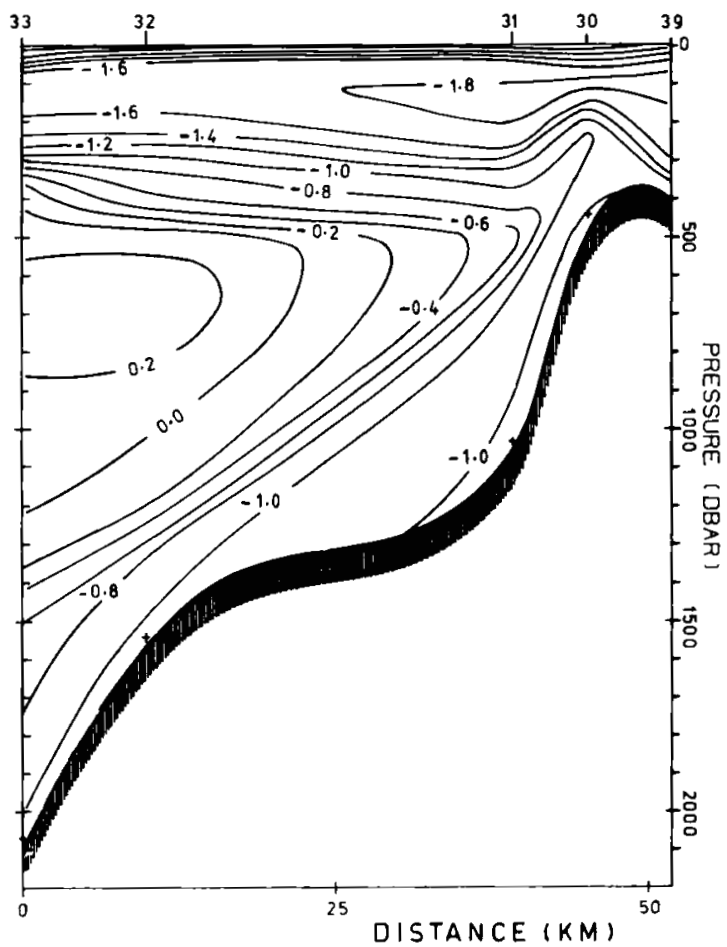

$b$

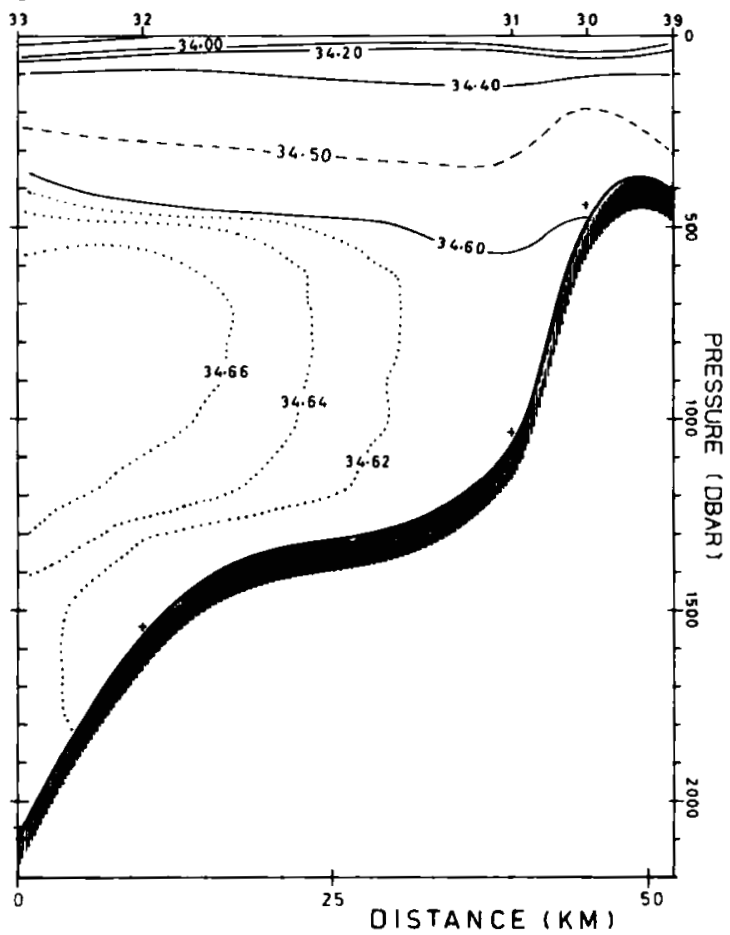

Fig. 17. Slope Section Center (stations 39 and 30-33). For location, see map (Fig. 2). Crosses denote maximum depth of individual soundings. a. Potential temperature $\left({ }^{\circ} \mathrm{C}\right)$; b. Salinity. 

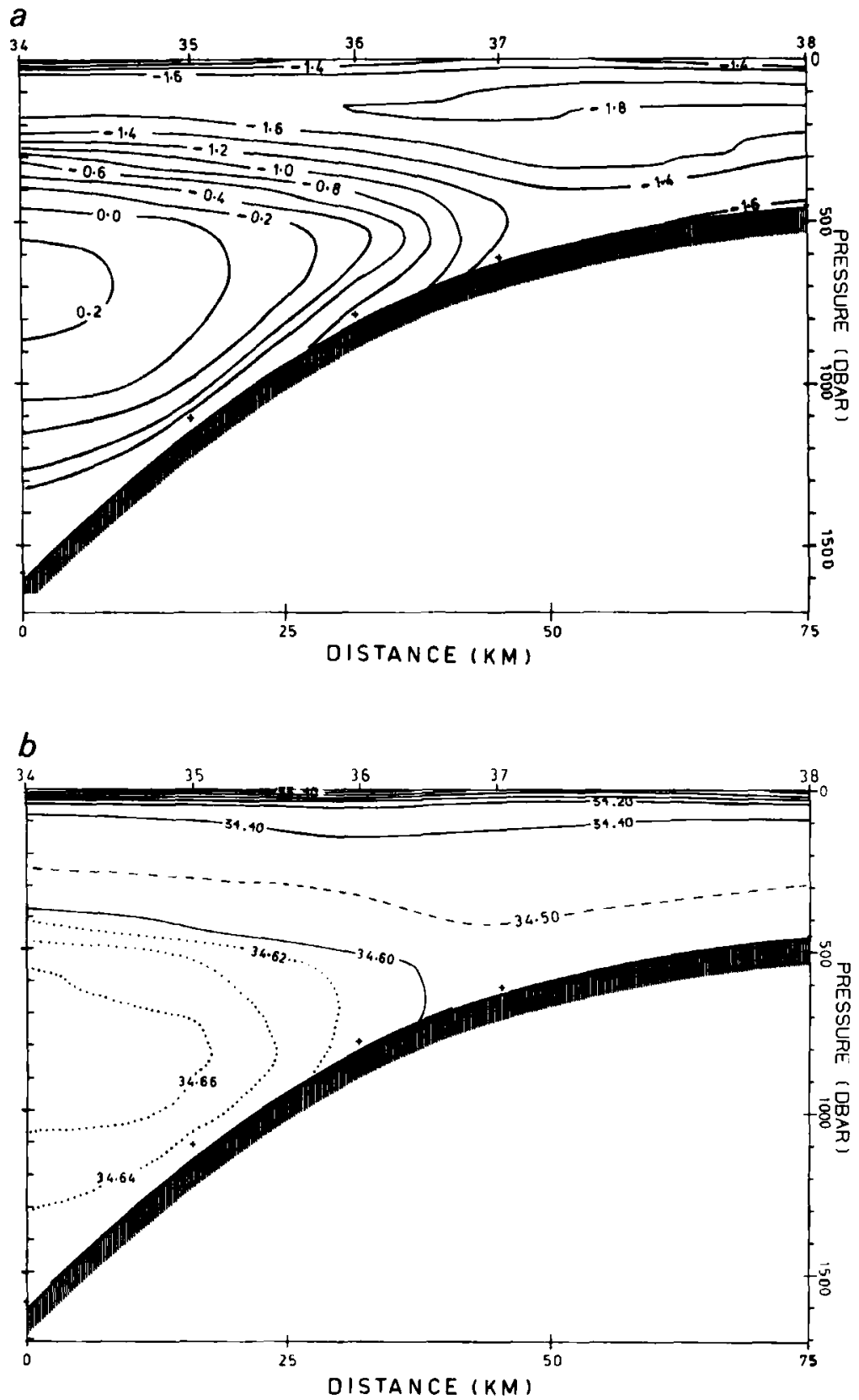

Fig. 18. Slope Section West (stations 34-38). For location, see map (Fig. 2). Crosses denote maximum depth of individual soundings. a. Potential temperature $\left({ }^{\circ} \mathrm{C}\right) ;$ b. Salinity.

VI. Ice Shelf Water appearing at the Filchner Ice Shelf follows the contours west of the Filchner Depression towards the sill where it is observed to overflow. This extremely cold water sinks towards the bottom of the Weddell Sea basin mixing with the surrounding Weddell Deep Water. The cold flow is easily identified below $2000 \mathrm{~m}$ depth by its extreme temperature gradients.
Acknowledgement. - Our sincere thanks are due to Captain $M$. Aklestad and his crew on board the R/V 'Polarsirkel' for highly efficient and professional assistance throughout the cruise. We also thank our colleagues R. Bø and H. G. Gade for their assistance in carrying out the field programme. We acknowledge the assistance of the Norwegian Research Council for Science and the Humanities through the research grant supporting $\mathrm{T}$. Tørresen and for the loan of the CTD equipment. We also gratefully acknowledge the assistance of B. Biskopshavn in producing the diagrams. 


\section{References}

Behrendt, J. C. 1962: Geophysical and glaciological studies in the Filchner Ice Shelf area of Antarctica. J. Geophys. Res. 67, 221-234.

Brennecke, W. 1921: Die ozeanographischen Arbeiten der deutschen antarktischen Expedition 1911-1912. Ark. Deutschen Seewarte 39, 214 pp.

Carmack, E. C. 1973: Silicate and potential temperature in the deep and bottom waters of the western Weddell Sea. Deep Sea Res. 20, 927-932.

Carmack, E. C. \& Foster, T. D. 1975a: On the flow of water out of the Weddell Sea. Deep Sea Res. 22, 711-724.

Carmack, E. C. \& Foster, T. D. 1975b: Circulation and distribution of oceanographic properties near the Filchner Ice Shelf. Deep Sea Res. 22, 77-90.

Carmack, E. C. \& Foster, T. D. 1977: Water masses and circulation in the Weddell Sea. Pp. 151-164 in Dunbar, M. (ed.): Polar Oceans. Arctic Institute of North America, Calgary, Alberta, Canada.

Deacon, G. E. R. 1937: The hydrography of the Southern Ocean. Discovery Reports 15, $124 \mathrm{pp}$.

Deacon, G. E. R. 1979: The Weddell gyre. Deep Sea Res. 26, 981-995.

Foldvik, A., Gammelsrød, T. \& Tørresen, T. 1985: Physical oceanographystudies in the Weddell Sea during the Norwegian Antarctic Research Expedition 1978/79. Polar Research 3n.s., 195-207 (this volume).

Foldvik, A. \& Kvinge, T. 1974a: Bottom currents in the Weddell Sea. Results of long time currentmeter moorings at $74^{\circ} \mathrm{S}$, $40^{\circ} \mathrm{W}$, during IWSOE 1968-1973. Univ. of Bergen, Geophys. Inst. div. A, Rep. 37.

Foldvik, A. \& Kvinge, T. 1974b: Conditional instability of sea water at the freezing point. Deep Sea Res. 21, 169-174.

Foldvik, A. \& Kvinge, T. 1977: Thermohaline convection in the vicinity of an ice shelf. Pp. 247-255 in Dunbar, M. (ed.): Polar Oceans, Arctic Institute of North America, Calgary, Alberta, Canada.

Foster, T. D. 1972: Haline convection in leads and polynyas. $J$. Physical. Oceanography 2, 462-469.

Foster, T. D. \& Carmack, E. C. 1976a: Frontal zone mixing and Antarctic Bottom Water formation in the southern Weddell Sea. Deep Sea Res. 23, 301-317.

Foster, T. D. \& Carmack E. C. 1976b: Temperature and salinity structure in the Weddell Sea. J. Phys. Oceanogr. 6, 36-44.
Gill, A. E. 1973: Circulation and bottom water formation in the Weddell Sea. Deep Sea Res. 20, 111-140.

Gordon, A. L. 1978: Deep Antarctic convection west of Maud Rise. J. Phys. Oceanogr. 8, 600-612.

Gordon, A. L. 1982: Weddell Deep Water variabilty. J. Marine Res. 40, Supplement, 199-217.

Gordon, A. L., Martinson, D. G. \& Taylor, H. W. 1981: The wind-driven circulation in the Weddell-Enderby Basin. Deep Sea Res. 28, 151-163.

Helland-Hansen, B. \& Nansen F. 1909: The Norwegian Sea Norw. Fish and Mar. Invest. Rept. 2 (182).

Huppert, H. E. 1971: On the stability of a series of doublediffusive layers. Deep Sea Res. 18, 1005-1021.

Lusquinos, A. J. 1963: Extreme temperatures in the Weddell Sea. Arbok for Universitetet i Bergen, Mat-Naturv. Serie, 23, I.

Martinson, D. G., Killworth, P. D. \& Gordon, A. L. 1981: A convective model for the Weddell Polynya. J. Phys. Oceanogr. 11, 466-488.

Middleton, J. H. \& Foster, T. D. 1980: Fine structure meas urements in a temperature-compensated halocline. $J$. Geophys. Res. 85, 1107-1122.

Millero, F. J. 1978: Freezing point of sea water. Eighth Report of the Joint Panel on Oceanographic Tables and Standards. Appendix 6, UNESCO Tech. Pap. Mar. Sci. 28, 29-35.

Mohn, H. 1887: Nordhavets dybder, temperatur og strømninger. Den norske nordhavs-Exped. 1876-1878 18, 212 pp.

Mosby, H. 1934: The waters of the Atlantic Antarctic Ocean. Scientific Results of the Norwegian Antarctic Expeditions 1927-1928 1(11), 131 pp.

Neshyba, S., Neal, V. T. \& Denner, W. 1971: Temperature and conductivity measurements under Ice Island T-3. J. Geophys. Res. 76, 8107-8120.

Reid, J. L. \& Lynn, R. J. 1971: On the influence of the Norwegian-Greenland and Weddell seas upon the bottom waters of the Indian and Pacific oceans. Deep Sea Res. 18, 1063-1088.

Røyset, H. \& Bjerke, P. E. 1982: CTD data processing program package. Univ. of Bergen, Inst. of Geophys., Dept. of Oceanogr., Technical Report, unpublished manuscript.

Sverdrup, H. U. 1940: Hydrology, Section 2, Discussion. B.A.N.Z. Antarct. Res. Exped. 1921-31, Reports, Ser. A. 3, Oceanography, Pt. 2, 88-126.

Wüst, G. 1938: Bodentemperatur und Bodenstrom in der atlantischen, Indischen und Pazifischen Tiefsee. Gerlands Beitr. Geophys. 54, 1-8. 